\title{
Keefektifan Media Audio Visual dalam Meningkatkan Kompetensi Siswa Sekolah Menengah Pertama dalam Menulis Puisi
}

\author{
Nurfaedah \\ Manajemen Informatika, STMIK Handayani Makassar \\ Email: nurfaedahkimya@gmail.com
}

\begin{abstract}
Penelitian ini bertujuan mendeskripsikan keefektifan media audiovisual dalam meningkatkan kompetensi siswa kelas VIII SMP Negeri 8 Makassar menulis puisi. Variabel penelitian ini adalah keefektifan media audiovisual dalam meningkatkan kompetensi siswa kelas VIII SMP Negeri 8 Makassar menulis puisi. Desain atau model penelitian adalah desain penelitian eksperimen. Populasi penelitian ini, yaitu keseluruhan siswa kelas VIII SMP Negeri 8 Makassar yang berjumlah 270 orang yang terbagi dalam sembilan kelas. Sampel penelitian sebanyak 30 dari jumlah populasi. Penarikan sampel menggunakan teknik cluster random sampling. Teknik yang digunakan mengumpulkan data adalah teknik tes. Data yang terkumpul dianalisis dengan menggunakan teknik statistik deskriptif dan teknik analisis uji t desain 2. Hasil penelitian ini menunjukkan bahwa media audiovisual efektif diterapkan dalam meningkatkan kompetensi siswa kelas VIII SMP Negeri 8 Makassar menulis puisi. Hal ini tampak pada nilai yang diperoleh siswa sebelum menggunakan menggunakan media audiovisual yang masih kurang dan dapat meningkat setelah menggunakan media audiovisual. Keefektifan media ini diketahui pula berdasarkan hasil perhitungan uji $t$. Perbandingan hasil kompetensi menulis puisi pada pretes dan postes menunjukkan bahwa nilai t hitung sebanyak 7,20> nilai t tabel 1,70. Hal ini menunjukkan bahwa hipotesis penelitian yang diajukan diterima, yaitu media audiovisual efektif diterapkan dalam meningkatkan kompetensi siswa kelas VIII SMP Negeri 8 Makassar menulis puisi.
\end{abstract}

Kata kunci: Media Audiovisual, Kompetensi, Menulis Puisi

\section{Effectiveness of Audio Visual Media to Improve the Competence of Junior High School Students in Writing Poetry}

\begin{abstract}
This study aims to describe the effectiveness of audiovisual media in improving the competence of eighth grade students of Makassar Middle School 8 writing poetry. The variable of this research is the effectiveness of audiovisual media in increasing the competency of the eighth grade students of Makassar Middle School 8 writing poetry. The research design or model is an experimental research design. The population of this study, which is all eighth grade students of Makassar Middle School 8, consist of to 270 students divided into nine class. The study sample was 30 of the population. Sampling uses cluster random sampling technique. The technique used to collect data is a test technique. The collected data were analyzed using descriptive statistical techniques and design t test analysis techniques 2. The results of this study indicate that audiovisual media is effectively applied in increasing the competency of VIII grade students of Makassar Middle School 8 writing poetry. This can be seen in the value obtained by students before using audiovisual media that is still lacking and can increase after using audiovisual media. The effectiveness of this media is also known based on the results of $t$ test calculations. Comparison of the results of writing poetry competencies on the pretest and posttest shows that the value of $t$ count is 7.20>t table 1.70. This shows that the proposed research hypothesis is accepted, that is, audiovisual media is effectively applied in increasing the competency of VIII grade students of SMP Negeri 8 Makassar writing poetry..
\end{abstract}

Kata kunci: Audio Visual Media, Competence, Writing Poetry

http://www.journal.univetbantara.ac.id/index.php/IJIMM 


\section{PENDAHULUAN}

Menulis adalah rangkaian proses berpikir. Proses berpikir berkaitan erat dengan kegiatan penalaran. Penalaran yang baik dapat menghasilkan tulisan yang baik pula. Menulis merupakan kegiatan penyampaian pesan dengan menggunakan tulisan sebagai mediumnya. Salah satu jenis tulisan sebagai suatu hasil pikiran adalah karya sastra, khususnya puisi.

Pembelajaran menulis puisi di SMP sesuai dengan Kurikulum Tingkat Satuan pendidikan bertujuan meningkatkan keterampilan siswa dalam berbahasa secara tepat dan kreatif, meningkatkan kemampuan berpikir logis dan bernalar, serta meningkatkan kepekaan perasaan dan kemampuan siswa untuk memahami dan menikmati karya sastra. Selain itu, pembelajaran menulis puisi dimaksudkan agar siswa terdidik menjadi manusia yang berkepribadian, sopan, dan beradab, berbudi pekerti yang halus, memiliki rasa kemanusiaan, berkepedulian sosial, memiliki apresiasi budaya dan penyaluran gagasan, berimajinasi, berekspresi secara kreatif baik secara lisan maupuan tertulis. Pembelajaran menulis puisi juga dimaksudkan untuk meningkatkan kemampuan siswa dalam menikmati menghayati, dan memahami karya puisi.

Menulis puisi sebagai salah satu aspek yang diharapkan dikuasai siswa dalam pembelajaran puisi menekankan pada kompetensi siswa mengekspresikan puisi dalam bentuk sastra tulis yang kreatif yang dapat membangkitkan semangat, pikiran, dan jiwa pembaca. Dengan demikian, pembaca dapat memperoleh hikmah berdasarkan puisi yang dibaca.

Pembelajaran menulis puisi di SMP selain bertujuan menggali dan mengembangkan kompetensi dasar siswa dalam mengapresiasi sastra, juga melatih keterampilan siswa menggali nilainilai yang terkandung dalam puisi sehingga dapat mencintai puisi yang pada akhirnya diharapkan mereka dapat menciptakan puisi-puisi yang bermutu.

Kompetensi dasar menulis kreatif (menulis puisi) itu mempunyai dua tujuan utama. Pertama, siswa menggunakan bahasa untuk memahami, mengembangkan, dan mengomunikasikan gagasan dan informasi, serta untuk berintegrasi dengan orang lain. Kedua, para siswa juga diharapkan dapat memahami dan berpartisipasi dalam kegiatan menulis kreatif agar mereka dapat menghargai karya artistik, budaya, intelektual, serta menerapkan nilai-nilai luhur untuk meningkatkan kematangan pribadi menuju masyarakat beradab (Depdiknas, 2006: 15).

Pembelajaran menulis puisi dapat membantu siswa untuk mengekspresikan gagasan, perasaan, dan pengalamannya. Seorang guru dapat membantu siswa mencurahkan isi batinnya, ide, dan pengalamannya melalui bahasa yang indah, dengan melatih siswa menulis puisi. Siswa akan termotivasi untuk belajar bermain dengan kata-kata, menafsirkan dunianya dengan suatu cara baru yang khas dan menyadari bahwa imajinasinya dapat menjadi konkret bila ia dapat memilih kata-kata dengan cermat untuk ditulis dalam puisi.

Berdasarkan uraian tersebut tampak bahwa pembelajaran menulis puisi sangat penting ditingkatkan dalam lingkup pendidikan. Menyadari pentingnya pembelajaran menulis puisi bagi siswa 
di SMP, maka pembelajaran tersebut perlu mendapat perhatian yang serius. Akan tetapi, kenyataan di lapangan menunjukkan bahwa pembelajaran menulis puisi di sekolah masih mengalami kendala dan cenderung dihindari oleh siswa. Hal ini disebabkan oleh tidak adanya pemahaman nilai dan manfaat lainnya yang dapat diperoleh siswa ketika menulis puisi. Selain itu, metode yang digunakan dalam pembelajaran puisi masih kurang sehingga minat dan kompetensi siswa menulis puisi juga tidak memadai.

Kendala yang terkadang ditemui oleh siswa dalam menulis puisi antara lain, siswa kesulitan menemukan ide, kesulitan menentukan kata-kata dalam menulis puisi, kesulitan dalam memulai menulis, kesulitan mengembangkan ide menjadi puisi karena minimnya penguasaan kosakata, dan kesulitan menulis puisi karena tidak terbiasa mengemukakan perasaan, pemikiran, imajinasinya, serta kurang mampu menghubungkan antara dunia khayal dengan dunia nyata ke dalam puisi.

Fenomena tersebut juga dapat dijumpai di sekolah-sekolah, seperti di SMA Negeri 1 Bajeng sebagai salah satu sekolah yang telah diteliti berdasarkan kompetensi menulis puisi. Hal ini dilakukan oleh Suhartini (2005: 59), dengan judul: Kemampuan Menulis Puisi Siswa Kelas III Bahasa SMA Negeri 1 Bajeng. Hasil penelitiannya tersebut menunjukkan bahwa siswa tidak mampu menulis puisi.

Isu dan masalah pembelajaran menulis puisi tersebut harus diatasi sehingga siswa dapat menulis puisi dengan jalan mencurahkan ide, bentuk-bentuk puitis, rima, dan aturan-aturan dalam menulis puisi. Salah satu langkah yang dapat dilakukan untuk mengatasi hal tersebut, yaitu menerapkan media yang menarik dan sesuai dengan karakter dan minat belajar siswa. Media yang dimaksud, yaitu audiovisual. Sangatlah efektif pembelajaran menulis puisi pada tingkat SMP jika siswa menulis puisi dengan bantuan media audiovisual. Melalui media tersebut siswa merasa mudah mengembangkan ide-idenya ke dalam bentuk puisi karena telah tampak gerakan-gerakan dan visualisasi suatu objek sehingga siswa tinggal memformulasikan objek itu melalui diksi menjadi puisi.

Audiovisual sebagai media pendidikan merupakan segala sesuatu yang dapat digunakan untuk menyalurkan pesan dari pengirim ke penerima sehingga dapat merangsang pikiran, perasaan, perhatian, minat, dan kegiatan siswa sedemikian rupa dengan tujuan memperlancar proses belajar mengajar. Melalui audiovisual, pembelajaran akan bermakna dan menarik sehingga menimbulkan daya tarik tersendiri bagi siswa untuk menulis puisi (Latuheru, 1993).

Penggunaan media audiovisual dalam pembelajaran menulis puisi diharapkan dapat memotivasi dan membantu siswa menciptakan ide, gagasan, dan mengembangkan gagasan itu menjadi sebuah karya sastra. Dengan demikian, dapat disimpulkan bahwa media audiovisual dapat diterapkan dalam pembelajaran menulis puisi siswa.

Berdasarkan uraian tersebut, penulis termotivasi melakukan penelitian dengan judul: "Keefektifan Media Audiovisual dalam Meningkatkan Kompetensi Siswa Kelas VIII SMP Negeri 8 Makassar dalam Menulis Puisi." Hal ini dilakukan karena penelitian yang relevan kurang mendapat perhatian. Padahal, penelitian hal ini sangat perlu dilakukan untuk menemukan pemahaman yang 
lebih ilmiah tentang peran media audiovisual dalam pembelajaran sehingga dapat diterapkan oleh guru dalam setiap pembelajaran.

Berdasarkan latar belakang yang telah dikemukakan, masalah penelitian ini, yaitu "Apakah media audiovisual efektif meningkatkan kompetensi siswa kelas VIII SMP Negeri 8 Makassar menulis puisi? Penelitian ini bertujuan mendeskripsikan keefektifan media audiovisual dalam meningkatkan kompetensi siswa kelas VIII SMP Negeri 8 Makassar menulis puisi.

\section{METODE}

Penelitian ini merupakan penelitian eksperimen dan dilakukan sebanyak 4 kali pertemuan, yaitu observasi, pretes (sebelum eksperimen), tindakan, dan kegiatan postes (setelah eksperimen) dengan memfokuskan pada satu kelas yang dijadikan sebagai sampel. Desain atau model penelitian yang digunakan dalam penelitian ini adalah desain penelitian yang bersifat eksperimen dengan pola sebagai berikut.

Pola: $01 \times 02$

O1: Tes kompetensi menulis puisi sebelum (treatmen)

O2: Tes kompetensi menulis puisi setelah (treatment)

(Diadaptasi dari Arikunto, 2006: 85).

Populasi penelitian ini, yaitu keseluruhan siswa kelas VIII SMP Negeri 8 Makassar yang berjumlah 270 orang yang terbagi dalam sembilan kelas. Populasi penelitian ini bersifat homogen karena penempatan siswa dalam suatu kelas tidak didasarkan pada tingkat prestasi belajar yang dicapai oleh siswa, tetapi berdasarkan nomor urut pendaftaran sejak masuk di sekolah ini. Penarikan sampel dalam penelitian ini menggunakan teknik cluster random sampling, artinya penentuan sampel secara acak dan dilakukan melalui undian dengan jumlah yang ditentukan sesuai dengan kebutuhan analisis. Jadi, sampel penelitian ini ditetapkan kelas VIII-3 sebanyak 30 dari jumlah populasi. Teknik yang digunakan untuk mengumpulkan data penelitian ini adalah teknik tes tertulis. Maksudnya, siswa ditugasi menulis puisi berdasarkan tema audiovisual yang didengar dan dipandang. Dalam penelitian ini, data yang terkumpul dianalisis dengan menggunakan teknik statistik deskriptif dan teknik analisis uji t desain 2. Adapun langkah-langkah menganalisis data adalah 1) membuat daftar skor mentah, 2) membuat distribusi frekuensi dari skor mentah, 3) untuk kepentingan standarisasi hasil pengukuran (skor) dilakukan tranformasi dari skor mentah ke dalam nilai berskala 1-100, 3) menetukan frekuensi kuantitatif perolehan nilai. Data yang diperoleh dari tabel frekuensi dan pensentase kemudian disimpulkan. Sampel dikatakan mampu apabila 85\% mendapat nilai 70 ke atas, sedangkan dikatakan tidak mampu apabila jumlah sampel kurang dari 85\% yang mendapat nilai 70 ke atas. 4) Menentukan perbandingan hasil pretes dan postes kompetensi siswa menulis puisi dengan rumus sebagai berikut. 


$$
t=\frac{M d}{\sqrt{\frac{\sum X^{2} d}{N(N-1)}}}
$$

Keterangan:

$$
\begin{array}{ll}
\mathrm{Md} & =\text { mean dari perbedaan pretes dan postes } \\
\mathrm{xd} & =\text { deviasi masing-masing subjek (d-Md) } \\
\sum X^{2} d & =\text { jumlah kuadrat deviasi } \\
\mathrm{N} & =\text { subjek/sampel } \\
\text { db. } & =\text { ditentukan dengan N-1 (Arikunto, 2006: 306). }
\end{array}
$$

\section{HASIL DAN PEMBAHASAN}

Pada bagian ini dipaparkan keefektifan media audiovisual dalam meningkatkan kompetensi siswa kelas VIII SMP Negeri 8 Makassar menulis puisi. Uraian keefektifan media audiovisual dalam meningkatkan kompetensi siswa kelas VIII SMP Negeri 8 Makassar menulis puisi merupakan gambaran keefektifan media pembelajaran menulis puisi. Keefektifan tersebut diukur berdasarkan perolehan nilai pretes (sebelum tindakan) dan nilai postes (setelah tindakan).

Tabel 1. Klasifikasi Kompetensi Siswa Kelas VIII SMP Negeri 8 Makassar Menulis Puisi sebelum Menggunakan Media Pembelajaran Audiovisual (Pretes)

\begin{tabular}{lcc}
\hline \multicolumn{1}{c}{ Skala Nilai } & Frekuensi & Persentase (\%) \\
\hline Nilai 70 ke atas & 16 & 53,34 \\
Nilai di bawah 70 & 14 & 46,66 \\
\hline Jumlah & 30 & $100 \%$ \\
\hline
\end{tabular}

Berdasarkan pada Tabel 6 di atas, dapat diketahui frekuensi dan persentase nilai kompetensi siswa kelas VIII SMP Negeri 8 Makassar menulis puisi sebelum menggunakan media pembelajaran audiovisual, yaitu hanya 16 siswa yang mampu mendapatkan nilai 70 ke atas $(53,34 \%)$ dan 24 siswa yang mendapat nilai di bawah 70 (46,66\%). Hal ini berarti kompetensi siswa kelas VIII SMP Negeri 8 Makassar menulis puisi sebelum menggunakan media pembelajaran audiovisual dikategorikan belum memadai. Hal ini dinyatakan karena hanya 16 siswa $(53,34 \%)$ yang mendapat nilai 70 ke atas. 
Tabel 2. Klasifikasi Kompetensi Siswa Kelas VIII SMP Negeri 8 Makassar Menulis Puisi dengan Menggunakan Media Pembelajaran Audiovisual (Post-test).

\begin{tabular}{lcc}
\hline \multicolumn{1}{c}{ Skala Nilai } & Frekuensi & Persentase (\%) \\
\hline Nilai 70 ke atas & 25 & 83,33 \\
Nilai di bawah 70 & 5 & 16,66 \\
\hline Jumlah & 30 & $100 \%$ \\
\hline
\end{tabular}

Berdasarkan pada tabel 2, dapat diketahui frekuensi dan persentase nilai kompetensi siswa kelas VIII SMP Negeri 8 Makassar menulis puisi dengan menggunakan media pembelajaran audiovisual, yaitu sebanyak 25 siswa yang mampu mendapatkan nilai 70 ke atas $(83,33 \%)$ dan 5 siswa yang mendapat nilai di bawah $70(16,66 \%)$. Hal ini berarti kompetensi siswa kelas VIII SMP Negeri 8 Makassar menulis puisi dengan menggunakan media pembelajaran audiovisual dikategorikan memadai. Hal ini dinyatakan karena sebanyak 25 siswa (83,33\%) yang mampu mendapat nilai 70 ke atas.

Pada bagian ini diuraikan temuan yang diperoleh dari hasil analisis data penelitian tentang keefektifan media audiovisual dalam meningkatkan kompetensi siswa kelas VIII SMP Negeri 8 Makassar menulis puisi. Uraian berikut ini pada dasarnya menggambarkan hasil pembelajaran menulis puisi dengan menggunakan media yang lazim digunakan guru di SMP Negeri 8 Makassar. Media yang digunakana sebagai sarana pembelajaran menulis puisi, yaitu media audiovisual atau penayangan film tsunami Aceh Desember 2004 lalu.

Berdasarkan hasil analisis data pretes bahwa rata-rata kompetensi siswa menulis puisi dikategorikan sedang. Dalam hal ini, masih banyak siswa yang kurang mampu menciptakan ide dan gagasan yang akan ditulis menjadi puisi sesuai dengan tema yang telah ditetapkan.

Fenomena menunjukkan bahwa siswa menulis puisi dengan berbagai kendala. Tampak sebagian siswa mengalami kebingungan, hanya tinggal diam, dan kurang bersemangat. Menurutnya, sulit berinspirasi untuk menciptakan tema dan judul untu dikembangkan ke dalam tulisan yang estetis dengan gaya bahasa, diksi, dan rima yang menarik. Fenomena lain yang tampak, yaitu ketika siswa menulis puisi, waktu yang digunakan rata-rata lama melewati batas waktu 2x45 menit. Hal ini disebabkan oleh sulitnya merangkaikan ide demi ide yang membentuk satu kesatuan ide dalam puisi.

Ditinjau dari aspek tema, banyak tema puisi siswa yang belum mencerminkan puisi yang menarik. Selanjutnya, terkadang isi puisi siswa tidak sesuai dengan tema. Isi puisi yang diungkapkan oleh siswa kurang menggugah rasa dan masih bersifat deskripsi dan naratif. Dengan demikian, tidak tampak keestetisan yang menarik dalam puisi siswa.

Segi amanat, tampak bahwa pengungkapan yang kurang jelas dan tidak dapat dipahami. Adapula amanat baik, tetapi terlalu bertele-tele. Pengungkapan amanat yang lain, yaitu amanatnya 
benar-benar tidak jelas sehingga tidak dapat dipaham. Bahkan, ada puisi siswa yang tidak menyiratkan pesan dan amanat dalam puisinya.

Aspek pengimajian, kurang menggambarkan sebagai puisi yang syarat dengan gambaran fenomena alam. Imaji yang digunakan maish kurang sehingga penggambaran realita kehidupan kurang tampak. Bahkan, ada pengimajian yang kurang bermakna. Terakhir yang tampak pada aspek ini, yaitu ada siswa yang tidak ada usahanya dalam mengembangkan daya khayal sehingga pengungkapan tidak hidup.

Diksi yang digunakan oleh siswa dalam menulis puisi menunjukkan bahwa sering menggunakan kata yang kurang tepat, banyak siswa yang salah menggunakan kata dan sangat sukar menggunakan kata secara tepat. Bahkan, ada siswa yang menulis puisi dengan kata-kata yang digunakan tidak terpilih sehingga makna yang diungkapkan sukar dipahami.

Aspek kata konkret, menunjukkan bahwa dalam menggambarkan suatu kiasan keadaan atau suasana batin kurang dapat membangkitkan imaji pembaca. Selanjutnya, tidak ada usaha siswa mengonkretkan kata-kata dalam puisinya sehingga tidak menyaran kepada arti yang menyeluruh. Bahkan, ada siswa yang menulis puisi yang tidak sama sekali memiliki usaha mengonkretkan katakata sehingga tidak menyaran kepada arti yang menyeluruh.

Aspek tipografi puisi siswa bervariasi. Ada siswa yang menulis puisi dengan penggunaan unsur tipografi sudah ada, tetapi kadang-kadang jalinannya tidak jelas. Selain itu, ada siswa yang menulis puisi dengan tidak mampu menggunakan unsur tipografi sehingga hampir sama dengan perwajahan dengan cerita biasa.

Aspek gaya bahasa, menunjukkan bahwa rata-rata siswa sering menggunakan gaya bahasa yang kurang tepat sehingga gaya bahasa tersebut kurang mengungkapkan suatu makna. Selain itu, ada siswa yang menulis puisi dengan gaya bahasa yang diungkapkan sangat terbatas sehingga makna yang diungkapkan tidak jelas.

Aspek nada puisi menunjukkan pula keragaman. Ada puisi dengan sedikit sekali menggunakan musikalitas. Selain itu, penggunaan musikalitas dalam puisinya kurang diperhatikan, penggunaan musikalitas dalam pengungkapannya tidak beraturan sehingga tidak menghidupkan makna yang disampaikan.

Fenomena yang dialami oleh siswa dalam menulis puisi sebelum menggunakan media audiovisual tersebut berdampak negatif terhadap nilai akhir yang diperoleh. Dapat diketahui bahwa frekuensi dan persentase kompetensi siswa menulis puisi, yaitu tidak ada siswa yang mampu mendapat nilai pada kategori sangat tinggi dan tinggi. Hal ini berarti bahwa nilai siswa berada pada kategori sedang. Dengan demikian, dapat dinyatakan bahwa kompetensi menulis puisi belum memadai.

Berbeda dengan fenomena dalam pembelajaran menulis puisi dengan menggunakan media audiovisual. Suasana pembelajaran mengalami perubahan positif yang signifikan. Terjadi suasana 
pembelajaran yang efektif dan menyenangkan bagi siswa, terutama pada saat menonton penayangan film bencana tsunami Aceh Desember 2004 minat dan motivasi siswa dalam belajar sangat tinggi yang ditunjukkan oleh reaksi siswa dalam belajar.

Fenomena menunjukkan dalam pembelajaran menulis puisi dengan menggunakan media audiovidual, yaitu masih ada siswa yang mengalami kesulitan menciptakan ide. Namun, frekuensi siswa yang mengalami hal ini lebih sedikit dibandingkan sebelumnya. Kendala tersebut dapat diatasi melalui penayangan film tsunami yang menarik, menggugah rasa kemanusiaan. Selain itu, tampak siswa seolah-olah menghayati dan meresapi langsung kejadian-kejadian itu. Berdasarkan penghayatan tersebut, tampak siswa mudah menciptakan ide.

Berdasarkan tanggapan sebagian siswa bahwa ada kemudahan menciptakan tema dan judul untuk dikembangkan ke dalam puisi karena suasana yang akan ditulis dalam puisi sudah dilihat, dirasakan, dan didengar langsung gejala yang terjadi. Fenomena lain yang tampak, yaitu ketika siswa menulis puisi, waktu yang digunakan rata-rata tepat waktu. Hal ini disebabkan oleh kemudahan siswa merangkaikan ide demi ide yang estetis sehingga membentuk satu kesatuan gagasan dan mengandung nilai serta pesan moral yang bermakna.

Ditinjau dari aspek tema, rata-rata puisi siswa mencerminkan tema puisi yang menarik. Selanjutnya, isi puisi siswa sesuai dengan tema. Isi puisi yang diungkapkan oleh siswa menggugah rasa dan mengandung nilai keindahan. Dengan demikian, tampak keestetisan yang menarik dalam puisi siswa. Segi amanat, tampak bahwa pengungkapan jelas dan dapat dipahami. Adapula amanat baik, benar-benar jelas sehingga dapat dipaham. Rata-rata puisi yang diciptakan merupakan sarana penyampai pesan kepada pembaca. Puisi siswa mencerminkan pula sebagai karya sastra yang sarat dengan nilai-nilai, seperti nilai agama, sosial, dan budaya. Aspek pengimajian, sudah menggambarkan sebagai puisi yang sarat dengan gambaran fenomena alam sesuai dengan film yang ditayangkan. Imaji yang digunakan menggambarkan realita kehidupan. Terakhir yang tampak pada aspek ini, yaitu ratarata siswa memiliki usaha dalam mengembangkan daya khayal.

Diksi yang digunakan oleh siswa dalam menulis puisi menunjukkan bahwa kata-kata yang digunakan sudah tepat. Bahkan, ada siswa yang menulis puisi dengan kata-kata yang digunakan merupakan suatu pilihan kata yang tidak diprediksi akan lahir dari imajinasi siswa. Melalui hal ini, tampak gaya (syle) terseniri bagi siswa dalam setiap puisinya. Aspek kata konkret, menunjukkan bahwa dalam menggambarkan suatu kiasan keadaan atau suasana batin dapat membangkitkan imaji pembaca. Selanjutnya, ada usaha siswa mengonkretkan kata-kata dalam puisinya sehingga menyaran kepada arti yang menyeluruh. Aspek tipografi puisi siswa mengalami perubahan sehingga tampak jelas perbedaannya dengan karangan atau karya sastra yang lain. Ada siswa yang menulis puisi dengan penggunaan unsur tipografi yang jalinannya sangat jelas. Selain itu, ada siswa yang menulis puisi dengan kompetensi yang tinggi menggunakan unsur tipografi sehingga benar-benar menampakkan karakteristik yang berbeda dengan karangan dan karya sastra yang lain. 


\section{KESIMPULAN DAN SARAN}

Berdasarkan hasil analisis data dan pembahasan dapat disimpulkan tentang keefektifan media audiovisual dalam meningkatkan kompetensi siswa kelas VIII SMP Negeri 8 Makassar menulis puisi. Hasil penelitian menunjukkan bahwa media audiovisual efektif diterapkan dalam meningkatkan kompetensi siswa kelas VIII SMP Negeri 8 Makassar menulis puisi. Hal ini tampak pada nilai yang diperoleh siswa sebelum menggunakan menggunakan media audiovisual yang masih kurang dan dapat meningkat setelah menggunakan media audiovisual. Keefektifan media ini diketahui pula berdasarkan hasil perhitungan uji t. Perbandingan hasil kompetensi menulis puisi pada pretes dan postes menunjukkan bahwa nilai t hitung sebanyak 7,20 > nilai t tabel 1,70. Hal ini menunjukkan bahwa hipotesis penelitian yang diajukan diterima, yaitu media audiovisual efektif diterapkan dalam meningkatkan kompetensi siswa kelas VIII SMP Negeri 8 Makassar menulis puisi. Hendaknya pembelajaran bahasa dan sastra Indonesia siswa kelas VIII SMP Negeri 8 Makassar lebih ditingkatkan dengan selalu memberikan pelatihan kepada siswa dalam menulis puisi dengan memperhatikan aspek-aspek menulis puisi. Guru hendaknya menggunakan media pembelajaran yang inovatif dan bervariasi dalam pembelajaran menulis puisi karena media yang inovatif dapat menciptakan situasi pembelajaran yang efektif dan menyenangkan serta membantu siswa menciptakan ide.

\section{DAFTAR PUSTAKA}

Ackhadiat, S, dkk., 1994. Pembinaan Kemampuan Menulis Bahasa Indonesia. Jakarta: Erlangga.

Arikunto, S. 2006. Prosedur Penelitian: Suatu Pendekatan Praktik. Jakarta: Rineka Cipta.

Azhar, A. 2002. Media Pengajaran. Jakarta: Raja Grafindo.

Depdiknas. 2006. KTSP Mata Pelajaran Bahasa Indonesia. Jakarta: Depdiknas.

Depoter, B. \& Hernacki, M., 2001. Quantum learning: Membiasakan Belajar Nyaman dan Menyenangkan. Terjemahan Abudurrahman Bandung: Kaifa.

Effendi, S., 1996. Bimbingan Apresiasi Puisi. Ende: Nusa Indah.

Firman. 2003. "Keterampilan Siswa Kelas II SLTPN 1 Sajoanging Kabupaten Wajo Menulis Pengalaman Pribadi dalam Bentuk Puisi." Skripsi. Makasar: FBS UNM.

Hartoko, A., 1989. Pengantar Ilmu Sastra. Surabaya: Usaha Nasional.

Latuheru, J.D., 1993. Media Pembelajaran dalam Pengajaran bahasa Indonesia. Ujung Pandang: IKIP Ujung Pandang.

Mirriam, C. 2006. Daripada Bete Nulis Aja. Bandung: KAIFA.

Nurgiyantoro, B. 2008. Penilaian Pengajaran Bahasa dan Sastra. Yogyakarta: BPEE.

Pradopo, Rahmat Djoko. 1999. Pengkajian Puisi. Yogyakarta: Gajah Mada University Press.

Sardiman, A. 2007. Media pendidikan: Pengertian, Pengembangan, dan Pemanfaatannya. Jakarta: Raja Grafindo Persada.

Semi, Atar. 1994. Kritik Sastra. Bandung: Angkasa.

Suhartini. 2005. "Kemampuan Menulis Puisi Siswa Kelas III Bahasa SMA Negeri 1 Bajeng/" Skripsi. Makassar: FBS UNM.

Sumardjo, J., 2001. Catatan Kecil tentang Menulis Cerpen. Yogyakarta: Pustaka Pelajar.

Syafi'i. 1998. Retorika dalam Menulis. Jakarta: Depdikbud.

Tarigan, H. G. 1990. Prinsip-prinsip Dasar Sastra. Bandung: Angkasa.

Waluyo, H. J. 1995. Teori dan Apresiasi Puisi. Jakarta: Erlangga.

Zulkarnaen, Y. 1984. Media dalam Pembelajaran. Jakarta: Rajawali. 